\title{
Strategi Pengembangan Padi Organik di Kota Padang
}

\author{
Organic Rice Field Development Strategy in Padang
}

\begin{abstract}
ABSTRAK
Di Kota Padang, kini mulai tumbuh pengusaha pertanian organik, mulai dari sayuran, buah-buahan hingga beras organik. Pada kenyataannya, petani masih sulit untuk mengembangkan budidaya padi organik dengan permasalahan luas lahan yang menerapkan sistem pertanian organik relatif kecil dan terletak di sekitar lahan budidaya non organik (konvensional). Penelitian ini bertujuan untuk memformulasikan strategi untuk mengembangkan agribisnis padi organik di Kota Padang. Metode yang digunakan adalah analisis SWOT dan rancangan arsitektur strategik. Berdasarkan hasil analisis matriks SWOT diperoleh lima strategi yaitu (i) Perluas Jaringan Pasar; (ii) Optimalkan penggunaan sarana produksi dengan modal yang tersedia; (iii) Tingkatkan promosi beras organik; (iv) Kembangkan produksi untuk memperoleh produktivitas yang lebih tinggi; dan (v) Berikan penyuluhan tentang manfaat dari padi organik. Dari lima strategi tersebut kemudian dipetakan kedalam rancangan arsitektur strategik dengan rentang waktu selama empat tahun.

Kata kunci : padi organik, SWOT, arsitektur strategik
\end{abstract}

\section{ABSTRACT}

In $t$ Padang, organic farming entrepreneurs are starting to grow, ranging from vegetables, fruits to organic rice field. In reality, farmers still find it difficult to develop organic rice (rice) cultivation with problems in the environment such as the area of land that applies organic farming systems is relatively small and is located around non-organic (conventional) cultivation lands. This study aims to formulate a strategy to develop organic rice field (rice) agribusiness in Padang. The method used is SWOT analysis and strategic architectural design. Based on the results of the SWOT matrix analysis, five strategies were obtained, namely (i) Extending the Market Network; (ii) Optimize the use of production facilities with available capital; (iii) Increase promotion of organic rice; (iv) Develop production to obtain higher productivity; and (v) Provide information about the benefits of organic rice. The five strategies are then mapped into a strategic architecture design with a span of four years.

Keyword : organik rice field, SWOT, architecture strategic

\section{PENDAHULUAN}

Deran sektor pertanian dalam
perekonomian nasional masih sangat besar terhadap pembentukan PDB nasional yaitu sebesar 13,45 persen pada tahun 2016 (Badan Pusat Statistik, 2017). Produkproduk pertanian sangat berguna dalam memenuhi kebutuhan masyarakat Indonesia terutama kebutuhan akan pangan. Indonesia memiliki beberapa komoditas pangan utama yaitu beras, jagung, kedelai, gandum dan kentang. Sejumlah 285 juta jiwa penduduk Indonesia mengkonsumsi hasil olahan beras yaitu nasi sebagai pangan utamanya, sehingga dapat menjadi peluang bagi petani produsen beras untuk mengembangkan usahanya.

Salah satu faktor utama penyebab penurunan produktivitas padi di Indonesia adalah penggunaan pupuk serta pestisida yang menyebabkan tanaman padi rentan 
terhadap hama, pencemaran air, udara dan kejenuhan tanah sehingga menurunkan produktivitas dan kualitas dalam jangka panjang serta menyebabkan produksi pangan tidak lagi aman untuk dikonsumsi karena menimbulkan penyakit bagi manusia (Saragih, 2008).

Program "Go Organik" yang dilakukan pemerintah merupakan salah satu cara untuk mempercepat terwujudnya pembangunan agribisnis berwawasan lingkungan (eco-agribusiness) guna meningkatkan kesejahteraan masyarakat, khususnya petani. Namun kenyataan dilapangan, petani masih sulit untuk mengembangkan budidaya padi organik dengan permasalahan yang ada di lingkungan seperti lahan petani yang berada di sekitar lahan yang mengusahakan pertanian konvensiaonal (anorganik). Masalah lain adalah luas lahan petani yang menerapkan sistem pertanian organik relatif kecil. Hal ini sejalan dengan penelitian Dudiagunoviani (2009); Safitri (2013) bahwa rata-rata petani yang membudidayakan padi oragnik mempunyai lahan disekitar pertanian anorganik (konvensional).

Posisi lokasi lahan organik yang bergabung dengan lahan konvensional seperti ini, dapat menimbulkan kekhawatiran dalam menjalankan budidaya pertanian organik khususnya padi organik, mempertahankan menjaga status organik air, lahan serta produk yang akan dihasilkan. Kemungkinkan terburuk yang dihadapi petani adalah lahan yang diusahakan secara organik terkena pencemaran pupuk kimia, pestisida kimia dan bahan kimia lainnya dari pertanian konvensional melalui air dan udara.

Permasalahan lain yang muncul dalam pengembangan padi organik di Kota Padang adalah rendahnya pemahaman petani tentang pertanian organik. Hutagaol dan Haryati (2013) mengatakan, jika melihat pemahaman petani tentang pertanian organik, terdapat beberapa variasi pemahaman petani mengenai pertanian organik ini. Ada petani yang memahami dan mempunyai keinginan berpindah ke pertanian organik dan masih ada pula petani yang bertahan dengan pertanian yang konvensional.

\begin{tabular}{|c|c|c|}
\hline $\begin{array}{l}\text { Penelitian } \\
\text { mformulasikan }\end{array}$ & ini & $\begin{array}{l}\text { bertujuan } \\
\text { strategi }\end{array}$ \\
\hline adang. & & \\
\hline
\end{tabular}

II. METODOLOGI

Penelitian ini dilaksanakan pada Kelompok Tani Padi Rimbun di Kecamatan Kuranji Kota Padang, dimana pemilihan kelompok tani ini dipilih secara purposive didasarkan pada pertimbangan Kelompok Tani Padi Rimbun merupakan kelompok tani yang pertama yang menerapkan budidaya padi organik di Kota Padang. Kelompok membudidayakan padi organik sejak tahun 2008 dengan memperoleh bantuan benih bersertifikat oleh Dinas Pertanian Kota Padang. Saat ini kelompok memiliki anggota 29 petani dengan luas lahan antara 0,25 ha sampai 1 ha. Produktivitas rata-rata padi organik yang ditanam oleh petani sebesar 5,04 ton/ha dengan varietas IR-42.

Jenis data yang digunakan dalam penelitian ini meliputi data primer dan data sekunder. Data primer diperoleh melalui wawancara dengan lima orang responden yang terdiri dari Kepala Bidang Pangan Dinas Pertanian Kota Padang, Penyuluh Lapangan, Kepala BPP Nangganlo, Pemilik Heler dan ketua kelompok tani. Sejumlah responden dipilih berdasarkan tingkat pengaruhnya terhadap perkembangan usaha kelompok tani Padi Rimbun.

Data sekunder diperoleh dari laporanlaporan lembaga yang erat kaitannya dengan produksi padi organik. Data penunjang lainnya didapat dari situs internet, artikel ilmiah, surat kabar dan penelitianpenelitian terdahulu.

Perumusan alternatif strategi bagi Kelompok Tani Padi Rimbun dilakukan dengan menggunakan analisis matriks SWOT untuk mengidentifikasi faktor-faktor secara sistematis untuk merumuskan strategi (David, 2009). 
Analisis matriks SWOT terdiri dari sembilan sel dengan empat sel faktor kunci, empat sel strategi dan satu sel yang dibiarkan kosong. Empat sel strategi terdiri dari strategi SO, strategi WO, strategi ST dan strategi WT (David, 2009).

Setelah melakukan analisis matriks SWOT dan menghasilkan strategi-strategi untuk pengembangan padi organik di Kota Padang, maka langkah selanjutnya adalah melakukan rancangan arsitektur strategi.

Rancangan arsitektur strategi berfungsi untuk melihat dan memetakan strategistrategi yang dihasilkan pada analisis SWOT berdasarkan prioritas dari strategi tersebut (Fauzi, 2013).

Arsitektur strategik merupakan gambaran rancangan yang bermanfaat untuk merumuskan strategi ke dalam sebuah roadmap untuk meraih visi dan misi perusahaan. Arsitektur strategik dipilih sebagai alat analisis dengan alasan bentuk ini lebih mudah untuk dipahami karena strategi yang akan dijalankan dijabarkan dalam bentuk gambar (Yoshida, 2006).

\section{HASIL DAN PEMBAHASAN}

\subsection{Analisis Matriks SWOT}

Analisis matriks SWOT merupakan langkah untuk memperoleh strategi dalam pengembangan padi organik di Kota Padang. Strategi-strategi tersebut dikelompokkan dalam empat sel, yaitu strategi SO, strategi WO, strategi ST dan strategi WT. Hasil analisis matriks SWOT dapat dilihat pada Tabel 1.

\section{Analisis Matriks SWOT Pengembangan Padi Organik di Kota Padang}

\begin{tabular}{|c|c|c|}
\hline & $\begin{array}{l}\text { STRENGTHS (S) } \\
\text { 1. Rasa kekeluargaan yang } \\
\text { tinggi } \\
\text { 2. Memiliki ketua kelompok } \\
\text { yang aktif } \\
\text { 3. Mengikuti pelatihan } \\
\text { 4. Sistem kemitraan dalam } \\
\text { kelompok tani } \\
\text { 5. Lokasi usaha yang } \\
\text { strategis } \\
\text { 6. Lahan milik pribadi } \\
\text { 7. Sistem perairan teratur } \\
\text { 8. Lahan yang sesuai } \\
\text { dengan komoditas padi } \\
\text { 9. Tersedianya sarana } \\
\text { produksi }\end{array}$ & $\begin{array}{l}\text { WEAKNESSES }(\mathrm{W}) \\
\text { 1. Modal terbatas } \\
\text { 2. Sistem pembayaran yang } \\
\text { kurang menguntungkan } \\
\text { petani } \\
\text { 3. Sumber daya petani } \\
\text { terbatas } \\
\text { 4. Penggunaan teknologi } \\
\text { masih sederhana } \\
\text { 5. Pemasaran terbatas }\end{array}$ \\
\hline $\begin{array}{l}\text { OPPORTUNITIES }(\mathrm{O}) \\
\text { 1. Hubungan dengan Dinas } \\
\text { Pertanian setempat } \\
\text { 2. Pendidikan dan kesadaran } \\
\text { masyarakat tentang } \\
\text { pentingnya hidup sehat } \\
\text { 3. Tersedianya bibit } \\
\text { bersertifikat organik } \\
\text { 4. Kemajuan dan inovasi } \\
\text { teknologi } \\
\text { 5. Adanya lembaga keuangan } \\
\text { yang menyediakan kredit }\end{array}$ & $\begin{array}{l}\text { STRATEGI S-0 } \\
\text { 1. Perluas jaringan pasar (S1, } \\
\text { S2, S3, S7, O1, O2) }\end{array}$ & $\begin{array}{l}\text { STRATEGI W-O } \\
\text { 1. Optimalkan penggunaan } \\
\text { sarana produksi dengan } \\
\text { modal yang tersedia } \\
(\mathrm{W} 1,04,06)\end{array}$ \\
\hline
\end{tabular}


6. Tingkat adopsi dan inovasi petani

\section{THREATHS (T)}

1. Peluang pasar

2. Adanya produk pengganti

3. Konversi lahan pertanian

4. Adanya peredaran padi organik palsu

5. Perubahan cuaca

6. Rentan terhadap serangan hama
STRATEGI S-T
1. Tingkatkan promosi beras organik (S5, S6, S7, S8, $\mathrm{T} 1, \mathrm{~T} 2, \mathrm{~T} 4)$

2. Kembangkan produki untuk memperoleh produktivitas yang lebih tinggi (S6, S8, S9, T3, T4, T5, T6)
Sumber : Data Primer, 2018 (diolah)

Dari Tabel 1 diperoleh rumusan strategistrategi untuk pengembangan padi organik di Kota Padang, yaitu :

\section{Strategi S-O}

Strategi S-O merupakan strategi yang dirancang dengan menggunakan kekuatan untuk mengambil keuntungan dari peluang yang ada (David, 2009). Dari hasil analisis diperoleh strategi S-O yaitu Perluas Jaringan Pasar. Dengan memperluas jaringan pasar, diharapkan petani padi organik memperoleh keuntungan yang lebih besar dibanding hanya menjual pada satu tengkulak saja. Disini petani dituntut untuk lebih kreatif dan banyak mencari informasi pasar.

Dalam penelitiannya, Siregar, dkk (2018) mengahasilkan strategi $\mathrm{S}-\mathrm{O}$ yaitu memanfaatkan peluang pasar yang tinggi dan harga jual yang stabil serta biaya produksi usahatani padi organik yang relatif lebih murah dari non-organik untuk dapat meningkatkan ketersediaan modal dan luas lahan.

\section{Strategi W-O}

Strategi W-O merupakan strategi yang dipakai oleh perusahaan untuk mengatasi kelemahan dengan memanfaatkan peluang yang ada (David, 2009). Strategi yang ditetapkan berdasarkan hasil analisis adalah optimalkan penggunaan sarana produksi dengan modal yang tersedia. Keterbatasan modal yang dimiliki petani,menuntuk petani untuk bisa memaksimalkan penggunaan sarana produksi yang ada untuk bisa melakukan budidaya padi organik. Karena pada umumnya petani padi organik pada
Kelompok tani Padi Rimbun memiliki modal usaha yang cenderung kecil. Hal ini disebabkan karena petani tidak mau melakukan pinjaman ke lembaga niaga yang ada disekitar tempat usaha mereka.

Siregar, dkk (2018) Dalam penelitiannya menghasilkan strategi W-O yaitu memanfaatkan harga padi organik yang stabil, cita rasa yang khas dan kebutuhan konsumen terhadap beras organik yang tinggi untuk mengatasi biaya upah buruh tani yang mahal dan menambah modal bagi kelompok tani.

\section{Strategi S-T}

Strategi S-T merupakan strategi yang menggunakan kekuatan yang dimiliki untuk menghindari ancaman-ancaman yang ada dalam pengembangan usaha (David, 2009).

Strategi S-T yang dihasilkan adalah tingkatkan promosi beras organik dan Kembangkan produksi untuk memperoleh produktivitas yang lebih tinggi.

Siahaan (2009) mengatakan strategi pengembangan produk merupakan strategi yang meningkatkan penjualan dengan memperbaiki atau memodifikasi produk/jasa. Produk yang selama ini diproduksi adalah padi anorganik yang masih mengandalkan pupuk dan pestisida anorganik.

\section{Strategi W-T}

Dari hasil analisis, strategi S-T yang dihasilkan adalah berikan penyuluhan tentang manfaat dari padi (beras) organik. Pada strategi ini peran penyuluh pertanian sangat dituntut untuk melakukan sosialisasi dan arahan-arahan dalam pengembangan 
padi organik, sehingga petani diuntungkan dalam melakukan budidaya padi organik.

Hal ini sejalan dengan penelitian Safitri (2013) yaitu melakukan pelatihan pencatatan dan analisis usahatani dengan memanfaatkan dukungan kelompok tani ataupun lembaga swadaya masyarakat.

\subsection{Rancangan Arsitektur Strategi}

Berdasarkan hasil wawancara dengan para pakar mengenai pengembangan agribisnis padi organik di Kota Padang, maka sasaran yang ingin dicapai serta tantangan yang dihadapi oleh Kota Padang dalam pengembangan padi organik adalah sebagai berikut :

1. Sasaran yang ingin dicapai oleh Kota Padang :

a. Menjadikan Padang sebagai Kota yang berorientasi pada Pertanian Organik khususnya Padi (beras) organik.

2. Tantangan yang dihadapi Kota Padang dalam pencapaian sasaran :
a. Sistem irigasi yang belum sesuai untuk pertanian organik
b. Lokasi sawah petani organik masih bercampur dengan petani konvensional (anorganik).

3. Tahapan Arsitektur Strategik

Rancangan arsitektur strategik untuk pengembangan padi organik di Kota Padang merupakan rekomendasi yang diberikan penulis sebagai jawaban atas tantangan yang dihadapi Kota Padang dalam pengembangan padi organik. Rancangan arsitektur strategik disusun dengan menggunakan input visi, misi dan tujuan dari Kota Padang dalam pengembangan padi organik, strategi-strategi yang dihasilkan dalam analisis SWOT, tantangan-tantangan yang dihadapi dan rentang waktu yang ditetapkan dalam pemetaan strategi.

Berdasarkan hasil diskusi dan wawancara dengan Dinas Pertanian Kota Padang, rentang waktu pelaksanaan strategi dalam pengembangan padi organik di Kota Padang adalah selama 4 (empat) tahun yaitu mulai dari tahun 2019 sampai tahun 2022. Rentang waktu ini ditetapkan sesuai dengan sasaran dan cita-cita Kota Padang untuk menjadikan Padang sebagai Kota yang berorientasi pertanian organik khusunya padi (beras) organik pada tahun 2022. Namun dalam pelaksanaannya terdapat tantangan yang dihadapi Kota Padang, diantaranya saluran irigasi yang belum sesuai untuk melakukan pertanian organik serta lokasi sawah petani organik yang masih bercampur dengan petani konvensional (anorganik).

Setelah melakukan serangkaian tahapan pendekatan untuk membuat rancangan arsitektur strategik yang kemudian hasilnya dipetakan kedalam gambar yang disebut Rancangan Arsitektur Strategik Pengembangan Padi Organik di Kota Padang.

Dari Gambar 1 dapat dijelaskan bahwa sumbu $X$ (horizontal) merupakan rentang strategi yang akan dijalankan sedangkan sumbu $Y$ merupakan rentang waktu dalam pelaksanaan strategi untuk pengembangan usaha. Berdasarkan tantangan yang dihadapi terhadap serangkaian strategi dan program unyuk menghadapi tantangan tersebut.

Terdapat dua kelompok strategi yang direkomendasikan untuk pengembangan padi organik di Kota Padang. Kelompok pertama adalah rangkaian strategi yang dilaksanakan secara terus menurus, sedangkan kelompok kedua merupakan strategi yang dilakukan secara bertahap sesuai kepentingan strategi tersebut dalam pengembangan padi organik di Kota Padang.

Kelompok pertama adalah strategi yang dilakukan secara terus menerus. Strategi yang dijalankan sejak tahun pertama penempatan arsitektur strategi sampai tercapainya sasaran yang telah ditentukan Kota Padang. Terdapat satu strategi yang akan dilaksanakan secara 
terus menerus yaitu berikan penyuluhan tentang manfaat dari padi dan bersa organik.

Kelompok kedua adalah strategi yang dilakukan secara bertahap yang dibagi kedalam rentang waktu tahun 2019, tahun 2020, tahun 2021 dan tahun 2022. Strategi yang masuk kedalam kelompok ini adalah :

(1) optimalkan penggunaan sarana produksi;

(2) kembangkan produksi; (3) tingkatkan promosi; dan (4) perluas jaringan pasar.

\section{KESIMPULAN}

Berdasarkan hasil analisis matriks SWOT diperoleh lima strategi yang direkomendasikan dalam pengembangan padi organik di Kota Padang. Dari lima strategi yang dihasilkan tersebut dipetakan kedalam rancangan arsitektur strategi yang dipetakan dalam rentang waktu 4 tahun, yakni mulai tahun 2019 sampai tahun 2022. Rancangan arsitektur strategik tersebut di bagi kedalam dua kelompok program yaitu kelompok program rutin berjalan dan kelompok program bertahap. 
Sumbu $X$

( Rentang Strategi)

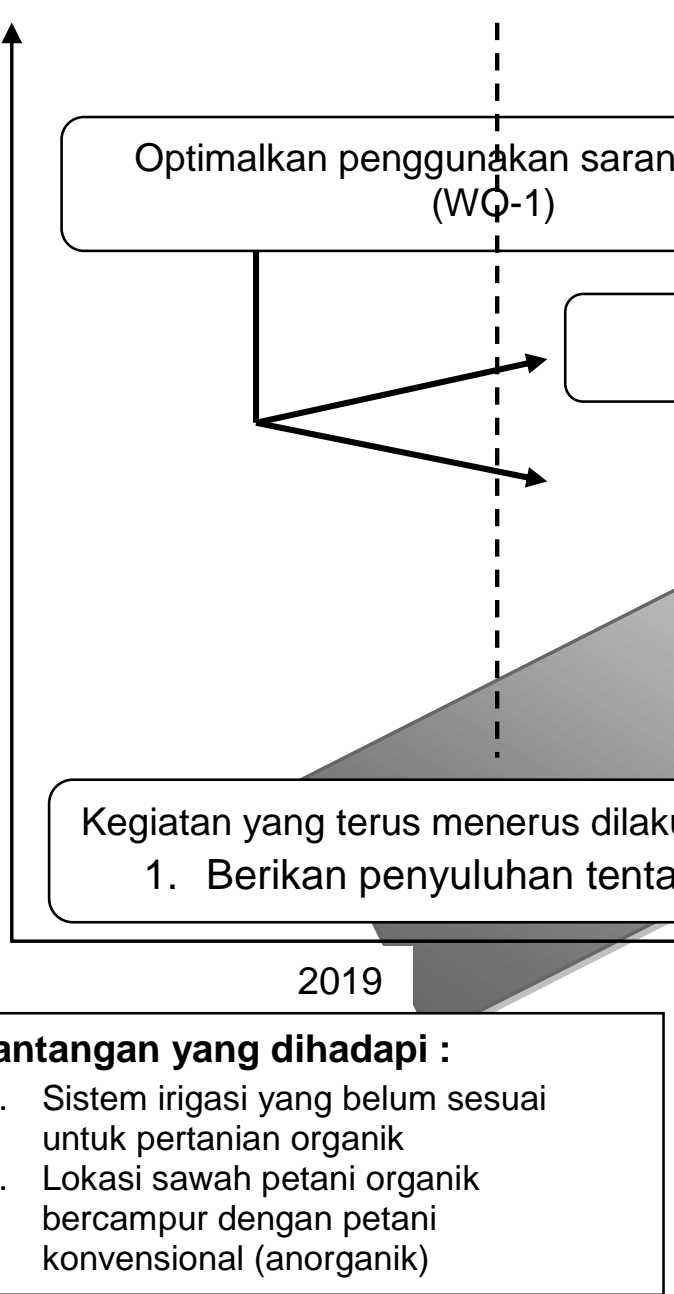

Sasaran dan tujuan :

Menjadikan Padang sebagai Kota yang berorientasi pertanian organik khususnya padi (beras) organik 


\section{DAFTAR PUSTAKA}

Badan Pusat Statistik. (2017). Statistik Indonesia 2017. (Sub-direktorat Publikasi dan Kompilasi Statistik, Ed.). Jakarta: Badan Pusat Statistik.

David, F. R. (2009). Manajemen Strategis. In P. Wuriarti (Ed.), 1 (12th ed., p. 559). Jakarta: Salemba Empat.

Dudiagunoviani, Y. (2009). Analisis strategi pengembangan usahatani beras organik kelompok tani cibeureum jempol.

Fauzi, D. (2013). Strategi Pengembangan Agribisnis Kentang Merah di Kabupaten Solok. https://doi.org/10.18196/agr.2129

Hutagaol MP; Haryati S. (2013). Ekonomi Pangan: Efektivitas Kebijakan Bantuan Langsung Benih Unggul Dan Pupuk Untuk Usahatani Pangan. Jurnal Pangan, 22(Ekonomi Pangan), 11-19. Retrieved from http://www.jurnalpangan.com

Safitri, S. A. (2013). Strategi Pengembangan Sistem Agribisnis Beras Organik.

Saragih, E. (2008). Pertanian Organik Solusi Hidup Harmoni. Jakarta: Penebar.

Siahaan, L. (2009). Strategi pengembangan padi organik kelompok tani sisandi, desa baruara, kabupaten toba samosir, sumatera utara.

Siregar, IA; Kesuma, SI; Jufri, M. (2018). Strategi pengembangan usahatani padi organik di desa karang anyar, kecamatan beringin, kabupaten deli serdang. Journal on Social Economic of Agriculture and Agribusiness, 9 No 3.

Yoshida, T. D. (2006). Arsitektur Strategik: Solusi Meraih Kemenangan dalam Dunia yang Senantiasa Berubah. Jakarta: Elex Media Komputindo. 